\title{
EL FÉNIX EN LAS MARIANAS (1747)*
}

\author{
POR
}

\author{
ALEXANDRE COELLO DE LA ROSA
}

Universitat Pompeu Fabra-CSIC

Este artículo analiza la ceremonia de coronación de Fernando VI en las islas Marianas -y las exequias de su padre, Felipe $V$, que la precedieron - como una representación barroca del poder (1747). Se trataba de dos funciones complementarias -Alejandra Osorio lo ha denominado las dos «caras de Jano»-que se orientaban a re-presentar la figura del monarca español y a reforzar la lealtad y fidelidad de sus súbditos en unas islas situadas en los márgenes del imperio

Palabras Clave: Jesuitas, islas Marianas, Fernando VI, Filipinas, coronación.

El 18 de junio de 1747 llegaron a las islas Marianas dos galeones que traían la triste noticia de la muerte de Felipe V (9/7/1746), así como varios papeles jurídicos, impresos, cartas y monedas de plata con la imagen del soberano esculpida en ellas. Ante esta noticia, el teniente general y gobernador de las Marianas, don Domingo Gómez de la Sierra (1746-49), informó a las autoridades y partidos de las islas y acto seguido notificó los festejos conmemorativos de la coronación de su hijo menor Fernando VI (1746-1759), príncipe de Asturias, «con gran magnificencia, celo y amor» ${ }^{1}$. Así, el 22 de julio de 1747, el se-

* El título de este ensayo se inspira en el libro editado por Pablo Fernández Albadalejo, 2006, 9-12. Agradezco la amabilidad y exquisito trato de Francesc Casanovas y del personal del Arxiu Històric de la Companyia de Jesús a Catalunya en la localización de libros y documentos.

1 Se trataba de las naves capitana «Nuestra Señora del Rosario», al mando del general don Francisco González de Quijano y la almiranta «Nuestra Señora del Pilar de Zaragoza», gobernada por el general don Juan Bautista Carranza, en los cuales viajaba el arzobispo de Manila, fray Pedro de la Santísima Trinidad («Llegada a las Marianas de dos navíos para anunciar la muerte de Felipe V y coronación de Fernando VI». Agaña, 18/6/1747 (AHCJC. 
cretario de la gobernación y guerra de las islas Marianas, don Jorge Eduardo del Castillo, acudió a la casa de los jesuitas en San Ignacio de Agaña, donde se encontraban presentes los padres Jacobo Heypel (1721-58)2 , vice-provincial de la misión, Joseph Bonani (1718-52)3 ministro del partido de Agat, Franz (Francisco Javier) Urfahrer (1724-66) ${ }^{4}$, ministro de los partidos de Inajaran, Merizo y Umatac, Wolgang Steinbeck (1734-67) ${ }^{5}$, rector del colegio de San Juan de Letrán, y Franz (Francisco Javier) Reittenberger (1708-1767)6 ${ }^{6}$ quien se ocupaba de evangelizar la isla de Rota ${ }^{7}$. El motivo de su visita era comunicarles mediante un decreto del 20 de julio la muerte del monarca ${ }^{8}$. Al mismo tiempo les notificó la voluntad del gobernador de celebrar el jueves día 27 de julio los oficios y exequias del difunto rey, y tres días después, el domingo 30 de julio, la salud y feliz coronación de su hijo menor Fernando VI (1746-1759), con la mayor pompa y suntuosidad que fuera posible. No era la primera vez que se celebraba el acto de investidura de un rey Borbón en Agaña. A pesar la pobreza y aislamiento de las islas, el 21 de septiembre de 1725 ,

FILPAS-093, Doc. 66, f. 1r). Véase también «Agaña, 18/6/1747» (AHCJC. FILHIS-061, E.I, c-5/4/1, f. 1 r).

2 El padre Jacobo Heypel nació en Treveris el 20 de octubre de 1687. Entró en la Compañía el 28 de septiembre de 1725. Era graduado y profeso de cuatro votos (1/11/1724). Murió en 1757 (ARSI, «Primus Catalogus Anni Personarum Anni 1746». Philippinae Cat. Trien. 1701-1755 1768, Tomo 3, f. 283r; Sommervogel, Tomo IV, 1960: 227).

3 El 2 de febrero de 1721, el padre Joseph Bonani hizo profesión de cuatro votos (ARSI, «Primus Catalogus Anni Personarum Anni 1725». Philippinae Cat. Trien. 1701-1755 1768, Tomo 3, f. 164v).

4 El padre Franz (Francisco Javier) Urfahrer nació en Ratisbona (Germania) el 28 de febrero de 1691. Entró en la Compañía de Jesús el 22 de septiembre de 1707. Era graduado y profeso de cuatro votos (24/8/1734) (ARSI, «Primus Catalogus Anni Personarum Anni 1746». Philippinae Cat. Trien. 1701-1755 1768, Tomo 3, f. 282r).

5 El padre Wolfang Steinbeck nació en Salzburgo el 24 de diciembre de 1699. Entró en la Compañía de Jesús el 14 de septiembre de 1719. Era graduado y profeso de cuatro votos (4/10/1736) (ARSI, «Primus Catalogus Anni Personarum Anni 1746». Tomo 3, f. $284 \mathrm{v})$.

${ }^{6}$ El padre Franz Reittenberger nació en Praga el 19 de junio de 1708. Entró en la Compañía de Jesús el 9 de octubre de 1722. En 1737 había hecho los votos de escolar. Murió en Agaña el 25 de octubre de 1767 (ARSI, «Primus Catalogus Anni Personarum Anni 1746». Tomo 3, f. 286r).

7 Por entonces la Compañía de Jesús tenía cuatro jesuitas destinados en Guam y uno en la isla de Rota. Junto con la de Guam constituía la única isla poblada de las Marianas (Carta del procurador Joseph Calvo, SJ, al rey Felipe V, fecha en 20 de junio de 1737, en Arxiu Històric de la Companyia de Jesús a Catalunya (en adelante, AHCJC), FILPAS-092, f. 51v. Junto a ellos se encontraba también el hermano coadjutor Luis García (1710-1754). Véase también Hezel, 1989: 60, 87 y 90).

8 Una copia de este decreto se encuentra en FILPAS-093, Doc. 66, ff. 3v-4r. 
don Manuel de Arguelles y Valdés (1725-30), gobernador y teniente general de las Marianas, había celebrado la abdicación de Felipe V con fecha en Madrid, 3 de febrero de 1724, a favor de su hijo primogénito Luis I (sólo reinó siete meses). Para celebrar su coronación mandó construir un catafalco desde el cual tomo el estandarte real y lo entregó al Alférez Real elegido a tal efecto, su hijo don Carlos de Argüelles y Valdés, en nombre de las islas Marianas, para que lo alzara y proclamara en honor del nuevo rey ${ }^{9}$. Acto seguido se formó una comitiva integrada por el gobernador y sus familiares, los funcionarios y vecinos, su hijo, el Alférez, que enarbolaba el pendón real con los escudos reales a un lado y los de la ciudad de Agaña, a otro, y cerraba el cortejo el escuadrón militar ${ }^{10}$. Se trataba de dos funciones complementarias - Alejandra Osorio lo ha denominado las dos «caras de Jano»_- que se orientaban a re-presentar la figura del monarca español y a reforzar la lealtad y fidelidad de sus súbditos en los márgenes del imperio, para lo cual solicitó la colaboración de los religiosos ${ }^{11}$.

\section{LAS ISLAS MARIANAS, UNA MISIÓN EN CRISIS}

La pretensión de celebrar dichas ceremonias resultaba chocante porque las Marianas no eran precisamente un ejemplo de suntuosidad y lujo cortesanos. Desde 1735 los jesuitas habían informado a los gobernadores de las Filipinas acerca del alarmante descenso demográfico en las islas ${ }^{12}$. El 30 de noviembre (o diciembre) de 1736, el padre Jacobo Heypel escribió una carta a su paisano, el padre Nicolás Mackinsck de la provincia del Rin inferior, en la que además confesaba la soledad y aislamiento de la vida misionera. Entre 1710 y 1720 sólo la mitad de los galeones que venían de Acapulco pararon en las islas. Y

9 Driver, 2005: 25-26.

10 AHCJC. FILHIS-061. E-I-c5 [r] Cuadernillo «Muerte de Felipe V y Coronación de Fernando VI (1747) en Agaña Marianas», ff. 2r-2v. Existe traducción en el Dossier Upon the Ocasion of the Royal Funerary Rites for Felipe V and the Proclamation of the Coronation of Fernando VI in the City of Agaña, 1747 (Micronesian Area Research Center (MARC), Working Papers \# 49), Mangilao, Guam, 1987). Cuando se llevó a cabo la ceremonia de la coronación de Luis I, el joven rey había muerto víctima de la viruela (31 de agosto de 1724), lo que confirma el aislamiento y la «insularidad» de las Marianas. Al respecto, véase también AHCJC. FILPAS-093, Doc. 66, f. 3r. Driver, 1984: 21.

11 Osorio, 2004: 473.

12 Carta del gobernador de las Marianas, firmada por el padre Joseph Bonani, SJ, con fecha en San Ignacio de Agaña, 2 de junio de 1735, «Testigo de haber sacado expediente sobre repoblación de las Marianas» (AGI, Filipinas, 149, Exp. 12). 
entre 1723 y 1726 no hubo ninguno ${ }^{13}$. En opinión del vice-provincial, esto era debido a la extrema pobreza de las islas,

c'est un pays piu montagneux, coupé de marécages, couvert per tout de rances, impropre par lui mime à produire la subsistance de l'home ${ }^{14}$.

Los gobernadores de las Marianas también aludían al «discurso de la pobreza» para justificar las estrecheces que padecían ${ }^{15}$. El aislamiento y las escasas rentas de las islas, unido a la insuficiencia de fondos para atender a los gastos de personal e infraestructura de los fuertes y presidios, constituían una de las principales preocupaciones de las autoridades civiles y eclesiásticas de Manila.

En las Marianas no había minerales o especias ni tampoco era posible establecer plantaciones con las que producir excedentes de manera intensiva. Al poco tiempo de tomar posesión de su gobierno (21/9/1746), el teniente general Gómez de la Sierra mandó fabricar un barco de veinte codos de quilla para conducir la carne desde la isla de Tinián al presidio de Agaña ${ }^{16}$. Desde hacía años las autoridades civiles se aprovechaban de las diferentes especies de ganado vacuno y porcino que pastaban libremente en las islas del norte después de haber reducido a su población en $1696^{17}$. El dato viene confirmado por el comandante Ansón, quien se aprovisionó en la isla por espacio de dos meses, describiéndola como una nueva Arcadia donde «abundaba toda clase de ganados». Además, nos dice que «había una porción de frutas, entre ellas naranjas, limones y cocos; que los españoles se aprovechaban de la fertilidad de esta isla para llevar víveres a Guam, y que no había más tropa que un sargento y veinte y dos indios que habían venido del mismo Guam para matar vacas y cargarlas en una canoa que se iba a marchar» ${ }^{18}$. Pero el patache que se encargaba del transporte se había extraviado en tiempos del sargento mayor y gobernador interino de las islas, don Miguel Fernández de Cárdenas (1740-46) ${ }^{19}$, sin que hubiera sido reemplazado. Mientras que los recursos parecían abundar largamente en Tinián ${ }^{20}$, los Reales Almacenes carecían de bastimentos y de lo más ne-

13 Hezel, 1989: 53.

14 AHCJC. FILCAR. E.I, a-18. Cartas de misioneros, 1677-1750», f. 356. Esta carta, escrita originalmente en francés, fue publicada en alemán por Stocklein, 1726-58.

15 Sobre el discurso de la pobreza en espacios de frontera, véase Vitar, 1997: 191-197.

16 AHCJC. FILPAS-093, Doc. 66, f. 11r.

17 «Relación de la conquista y restauración de las islas Marianas. 1696» (ARSI, Litterae Annuae Philipp. 1663-1734 (etiam de Insuli Marianis), Tomo 13, ff. 306r-307v).

18 Ansón, 1833, Tomo II: 181. Véase también Carano \& Sánchez, 1965: 96-97.

19 Como señala Driver (1984: 26), en 1744 el gobernador Fernández de Cárdenas finalizó las obras del palacio de Agaña.

20 Al respecto, véase Ansón, 1833, Tomo III, Capítulos I-IV: 5-61. 
cesario para la conservación de las islas, como hierro, pólvora, balas de plomo y pertrechos militares ${ }^{21}$. Desde 1737 habían diversas baterías instaladas en lo alto de los fuertes de Santo Ángel, en Umatac, y en el de San Luís, en el nuevo puerto de Apra, situado en la punta de Santiago de Orote, que protegían la isla de Guam de piratas ingleses que hostigaban a los galeones españoles cargados con la plata de Acapulco ${ }^{22}$. En 1725 el gobernador Argüelles ya había notado que las defensas de los fuertes estaban deterioradas, pero poco se hizo para mejorar las condiciones del presidio ${ }^{23}$. No fue hasta 1746 que el gobernador Gómez renovó la artillería, que estaba defectuosa o inservible. Mientras tanto, en España, tras la firma del Tratado de Aquisgrán (1748) los secretarios de estado y de gobierno, como el marqués de Ensenada, ministro de la Marina entre 1743 y 1754, incentivaron la defensa y fortificación de los litorales desde la Florida $(1718,1721)$ hasta la fundación de Montevideo (1730), así como la modernización de las fuerzas navales para defender un vasto imperio ultramarino $(1749)^{24}$.

Como uno de los precursores del reformismo ilustrado en las Filipinas, el Procurador General de la Compañía de Jesús, Joseph Calvo ${ }^{25}$, escribió dos Memoriales, con fecha en Manila, 27 de noviembre de 1745, en los que recomendaba al rey la urgente reforma del presidio en las Marianas ${ }^{26}$. El 20 de ju-

21 AHCJC. FILHIS-061. E-I-c5 [r] Cuadernillo «Muerte de Felipe V y Coronación de Fernando VI (1747) en Agaña Marianas», ff. 20r-20v. La construcción de los Reales Almacenes data de 1736. A su llegada a las Marianas en 1794, el gobernador coronel Manuel Muro (1794-1802) encontró graves deficiencias en su construcción, procediendo a su reforma, concluida en 1799 (Galván Guijo, 1998: 100).

22 Delgadillo, McGrath \& Plaza, 1979: 1-2. El puerto de Apra se abrió en 1737 para facilitar el amarre de los galeones y proveer a los pataches que llegaban de Manila (Hezel, 1989: 58; 2003: 257).

23 Hezel, 2003: 254-55.

24 Aunque en 1717 se creó una especie de escuela naval en Cádiz (Academia de Guardias Marinas), las grandes reformas datan del reinado de Fernando VI (1746-1759). En efecto, fue el marqués de la Ensenada, ministro de la Marina entre 1743 y 1754, quien modernizó y fortaleció la marina española con el fin de garantizar la seguridad de sus comunicaciones y proteger así el monopolio comercial con sus colonias de América y el Pacífico sur. Para ello se ocupó del reclutamiento de las tripulaciones y de modernizar el armamento (Parry, 1971). Un programa acertado que, para su total cumplimiento, hubiera requerido de unos recursos de los que la hacienda real no disponía (Stein \& Stein, 2002: 304-312).

25 El padre Joseph Calvo nació en Agreda el 21 de marzo de 1681. Entró en la Compañía de Jesús el 8 de diciembre de 1700. Era graduado y profeso de cuatro votos (15/8/1717) (ARSI, «Primus Catalogus Anni Personarum Anni 1737». Philippinae Cat. Trien. 1701-1755 1768, Tomo 3, f. 196v).

${ }^{26}$ Como ya señaló Horacio de la Costa, el padre Calvo «offered constructive suggestions for the economic development of the colony which anticipated those of the most enlightened 
nio de 1737, cuando gobernaba el capitán general de las Filipinas, don Fernando Valdés Tamón (1729-39), se hizo una Junta con los oidores y oficiales reales de la Audiencia así como con dos jesuitas que habían sido misioneros en aquellas islas. Decían que a consecuencia de las epidemias y las guerras los nativos habían disminuido considerablemente, y con ellos, la mano de obra que les podría permitir obtener algún género de riqueza o beneficio. De los miles de indios que hallaron los jesuitas a su llegada en 1668, apenas se contabilizaban 2.700 repartidos entre las islas de Guam y Rota ${ }^{27}$. Por esta razón la Junta acordó que era indispensable reducir el destacamento de 130 soldados que había en 1736 a 25 o 30 al mando de un cabo o sargento mayor con 600 pesos de sueldo, con lo cual se obtendrían muchos beneficios. En primer lugar, la Real Hacienda podría ahorrarse 11.000 pesos anuales en concepto de sueldos que podrían destinarse a otros presidios de mayor necesidad, como el de Zamboanga, restablecido en 1718, que debía proteger a los cincuenta padres jesuitas, que a juicio del procurador, serían destinados próximamente a las nuevas misiones en los sultanatos de Joló y Tamontaca ${ }^{28}$. En segundo lugar,

ministers of the Bourbon regime» (1989: 581) A modo de ejemplo, el jesuita Joseph Calvo presentó al ministro Gálvez un amplio proyecto para el desarrollo económico, con fecha en México, 20 de marzo de 1753, consistente en la reforma de la agricultura, la minería y la lucha contra la «corrupción» del archipiélago filipino. Se trataba de la creación de una compañía mercantil a imagen de las que existían en Inglaterra, Holanda y Francia —el embrión de la futura Real Compañía de Filipinas - que hiciera la ruta directa desde Acapulco a Veracruz rodeando el cabo de Hornos. Sus barcos podrían ahorrar los gastos de equipamiento del galeón de Acapulco, asegurar las comunicaciones entre España y Filipinas y proveer a España de las especies traídas de las islas (García-Abasolo, 2000: 223. Díaz Trechuelo, 1963: 197-201; 2002: 90-91).

27 El dato viene confirmado por otro jesuita, el misionero Joseph Bonani destacado en la isla de Guam, quien escribió una carta con fecha en Agaña, 1 de enero de 1740, en la que describía la alarmante disminución demográfica de las islas Marianas a una persona anónima de Viena (AHCJC. FILCAR. E.I, a-18. «Cartas de misioneros, 1677-1750», f. 251).

28 Es de sobras conocido que Joseph Calvo, procurador de la Compañía de Jesús, había defendido la necesidad de establecerse en esa nueva «frontera de la cristiandad» que constituían los reinos de Zamboanga y Joló (Real Academia de la Historia, Fondos Cortes, 567, 9-2674; Josep Calvo, «Información sobre el presidio de Zamboanga», Biblioteca Nacional, Sala Cervantes, Libros Filipinos de don Antonio Griaño, R/33375/7). A diferencia de cien pesos y cien fanegas de arroz que se acostumbraba a dar a los misioneros de las Filipinas, los misioneros destinados a Joló y Tamontaca obtendrían, según el padre Calvo, doscientos pesos de limosna (AHCJC. FILPAS-092, f. 54v). Asimismo, recomendaba subir el salario del gobernador de Zamboanga a 1.000 pesos, de manera que no tuviera que valerse «de otros arbitrios» (AHCJC. FILPAS-092, f. 52r). Al respecto, véase también la «Carta del arzobispo gobernador de Manila a su Majestad. Da cuenta con testimonio de haberse continuado las providencias sobre el restablecimiento del presidio de Zamboaga y quedar libre del sitio que le pusieron los reyes de Joló y Mindanao», con fecha en Manila, 14 de julio de 1721 (AHCJC. FILPAS-078, 1721, f. 98). El padre Calvo fue, además, un reformista ilustrado que ponderó los beneficios de la canela. Para ello recomendaba el 
con dicha reducción la Corona evitaría los gravámenes que los gobernadores, oficiales y soldados inflingían a sus moradores. En efecto, los españoles los utilizaban arbitrariamente para diversos negocios, como la manutención del palacio del gobernador, el cultivo de las sementeras de su propiedad y de los padres, el cuidado de varios gallineros de aves y corrales, así como del ganado vacuno y porcino con el que abastecían a la infantería, lo que era la principal causa de su rápida disminución. Años atrás este trabajo se repartía entre muchas más familias, pero ahora se cargaba sobre las espaldas de muy pocas $\sin$ prácticamente ninguna paga, a excepción de alguna ropa y hojas de tabaco, sin que vieran nunca un real de plata ${ }^{29}$. El procurador Joseph Calvo valoraba la situación con estas contundentes palabras:

Antes el trabajo para todo lo dicho se repartía entre millares de familias, y ahora no llegan a quinientas las que han de hacer lo mismo: ¡Cómo, pues, no han de ir cada año en disminución! ¡Cómo no se ha de experimentar que las indicas casadas con indios, o no tienen hijos, o son muy pocos cuando al contrario las casadas con soldados tienen muchos! ¡Y a qué otra causa se puede atribuir esta diferencia si no a que las segundas están exentas de trabajo y las primeras tan apuradas de él, que, o no tienen virtud para concebir, o se esterilizan a propósito por no parir esclavos para el español como se les ha oído decir alguna vez! Es pues, manifiesto, que no sólo es conveniente sino necesaria la dicha reforma para el alivio de los indios y que no se acaben de una vez $z^{30}$.

Además, sugería que los soldados no pudieran actuar sin el parecer y el consentimiento del superior de la misión ${ }^{31}$. Pero la Corona no estaba dispuesta a reducir su presencia militar en las Marianas ni tampoco a someterla a la supervisión religiosa. La situación había llegado a tal extremo que de los 2660 chamorros contabilizados en 1737 se habían pasado a apenas 1816 individuos en $1741^{32}$. En este contexto se produjo un intento de recuperación del nivel de-

establecimiento de colonos españoles en las islas (Archivo Histórico de la Compañía de Jesús de la Provincia de Toledo, Filipinas, C-285, Documento 7. «Otro Memorial del mismo Padre Calvo al rey con un informe sobre la conveniencia de conservar el presidio de Zamboanga», ff. 33r-66r). Documento 8. «Otro Memorial del mismo padre Calvo al Rey proponiendo medidas de que se forma población de españoles en Zamboangan», ff. 67r-70v).

Para una información más general sobre el tema, véase De la Costa, 1967: 542-551.

29 AHCJC. FILPAS-092, f. 50v.

30 AHCJC. FILPAS-092, f. 54r.

31 AHCJC. FILPAS-092, f. 51r.

32 ARSI, «Catalogus Christianorum quos colit societas in Philippinis. Anno 1737», Tomo 14. Supplementum ad Historiam, 1584-1750, f. 110r. En 1743, la cifra aumentó ligeramente a 2720 chamorros comprendidos en las islas de Guam (Agat, Merizo, Pago, Umatac e Inarahan), Rota y Saipan (ARSI, "Catalogus Christianorum quos colit societas in Philippinis. Anno 1743», Tomo 14. Supplementum ad Historiam, 1584-1750, f. 117r). 
mográfico del archipiélago. El 9 de julio de 1739, el gobernador de las Filipinas, don Fernando Valdés Tamón, ordenó remitir cien familias a las islas ${ }^{33}$. Posteriormente, el gobernador entrante, don Gaspar Antonio de la Torre y Ayala (1739-45), aplicó la Real Cédula del 28 de mayo por la que se ordenaba que no se forzase a los nativos a realizar trabajos que fueran superiores a su fuerza. Asimismo dictaminaba el restablecimiento y conservación de la economía productiva de las islas y de sus naturales. Se procedió a una colonización lenta y progresiva mediante el traslado de seis familias tagalas cada dos años, a fin de repoblarlas y evitar así una lenta pero inexorable despoblación ${ }^{34}$. En su Historia General de las Filipinas (1751), el jesuita Juan José Delgado ${ }^{35}$ confirmaba el dato de su cofrade jesuita y reconocía sin ambages que los chamorros apenas llegaban a tres mil almas. Pero a diferencia del procurador Calvo, las causas de este colapso demográfico eran ajenas a los españoles. En primer lugar, señalaba las epidemias como la principal causa de la disminución, sin menospreciar otras, como su obstinación por aceptar la dominación colonial. Esta «soberbia y altivez» se expresaba en una resistencia pasiva a través de suicidios individuales («muchos se ahorcan y otros se matan») o fugas colectivas a otras islas lejanas. Las mujeres, por su parte, evitaban quedarse embarazas, y las que lo hacían, abortaban o practicaban el infanticidio «por librarlos de la sujeción de los españoles» ${ }^{36}$. En 1702, el padre Lorenzo Bustillos ya había escrito sobre la tendencia de los chamorros al suicidio para evitar ser reducidos a trabajos forzados ${ }^{37}$. Sin embargo, el padre Delgado iba más allá, acu-

33 Carta del gobernador Fernando Valdés Tamón, con fecha en Manila, 9 de julio de 1739, en «Testigo de haber sacado expediente sobre repoblación de las Marianas» (AGI, Filipinas, 149, Exp. 12).

34 AHCJC. FILPAS-092, ff. 54v-55r. Farrell, 1991: 181-185. Brunal-Perry, 2001: 403. El 31 de julio de 1748, fray Juan de Arechederra, obispo electo de Nueva Segovia y gobernador interino de las Filipinas (1745-50), escribió a Fernando VI comunicándole las diligencias practicadas en cumplimiento de la Real Cédula de 1741 para el restablecimiento y conservación de las Marianas (AHCJC. FILPAS-093, Doc. 27, f. 257). Sorprende que el historiador Vicente Rodríguez García, en su trabajo sobre el gobernador Gaspar de la Torre, no haya entendido la importancia de estas reformas para la monarquía española (1976: 86-87).

35 El padre Juan José Delgado nació en Cádiz el 23 de junio de 1697. Entró en la Compañía de Jesús el 15 de mayo de 1714. Era graduado y profeso de cuatro votos (8/12/1731) (ARSI, «Primus Catalogus Anni Personarum Anni 1737». Philippinae Cat. Trien. 1701-1755 1768, Tomo 3, f. 198v).

36 Delgado, SJ, Libro 1, Cap. 33, [1751] 1892, f. 119v. Muñoz Barreda (1894: 48) coincidía con el parecer del padre Delgado en que la crisis no era atribuible a los colonizadores, sino a la resistencia de los chamorros a aceptar la dominación colonial.

37 «Carta del padre Lorenzo Bustillos al General Tirso González», con fecha 14 de abril de 1702 (ff. 326r-326v). «Reparos sobre el arbitrio y lo imposible de su ejecución», con fecha 
sándolos de su propia disminución. Su obstinada resistencia al modelo colonial no sólo provocó su propia ruina, sino la de los españoles, haciendo responsables a los primeros de la pobreza de las islas Marianas.

Debido a la gran penuria y escasez de recursos los chamorros supervivientes no pagaban tributo. Tampoco los repartimientos forzosos de mercancías - o de dinero - parecían haberse estabilizado como «una forma extra-jurídica de tributación» que los españoles impusieron con éxito en las islas Filipinas ${ }^{38}$. La alarmante disminución demográfica de los chamorros obligaba a los galeones y pataches a proveer a las Marianas de todos los bastimentos necesarios para su sustento. Una situación que como diría Josep Maria Fradera, difícilmente puede ser considerada estrictamente como «colonial» $»^{39}$. Más que proporcionar recursos a la metrópoli, aquellas islas resultaron ser una carga onerosa que no obstante se mantuvo bajo la administración española hasta el Tratado de París de 1898. Situadas en la retaguardia del imperio español, las Filipinas - y por ende, las Marianas - contenían el avance de las potencias extranjeras. Manila constituía la base de un comercio con China y el sudeste asiático vía Acapulco que los comerciantes de la Nueva España no querían perder ${ }^{40}$. Sin embargo, la presencia de los ingleses en el Pacífico se había incrementado a raíz de la guerra de sucesión a la corona de Austria y amenazaba el tráfico regular de los galeones de la ruta Manila-Acapulco ${ }^{41}$.

El 20 de junio de 1743 el galeón «Nuestra Señora de Covadonga» en el que viajaba don Isidro Álvarez de Nava, nombrado gobernador de las islas Marianas, fue apresado por el comandante inglés George Anson en el cabo del Espíritu Santo, tras un duro combate que le reportó unos beneficios de un millón y medio de pesos ${ }^{42}$. Al llegar a Manila en diciembre de 1743 el gobernador hizo gestiones para fletar por su cuenta una embarcación particular que salió de Cavite en junio de 1744 con dirección a la isla de Guam. Pero nunca llegó a su destino $^{43}$. El 14 de junio de 1743 el gobernador don Gaspar de la Torre y Ayala acusó recibo de la Real Cédula fechada el 28 de mayo de 1741 sobre la crítica situación de las Marianas en la que se confirmaba la necesidad de proporcio-

10 de abril de 1702 (ARSI, Tomo 13. Litterae Annuae Philipp. 1663-1734 (etiam de Insuli Marianis), f. 331r).

38 O'Phelan, citado Álvarez, 2000: 170-216.

39 Fradera, 2002: 107.

40 Hezel, 1989: 56; Fradera, 2002: 107-108.

41 Díaz-Trechuelo López Spínola, 1984: 129-153.

42 Como señala Rodríguez García, hacía dos años que los galeones de Manila no habían llegado desde Acapulco. Así pues, se esperaba que el galeón de 1743 trajera los reales situados de 1741 y 1742; o sea, mucho dinero (1976: 176-79).

43 Rodríguez García, 1976: 87. 
nar alivio material y espiritual a sus habitantes ${ }^{44}$. En los últimos cuatro años (1743-47) el comandante Anson había tratado de romper el monopolio comercial de España en sus territorios de ultramar, impidiendo la llegada de galeones con el «real situado» a las Marianas. En 1744 no se despachó ningún galeón y desde Madrid se ordenó interrumpir totalmente el comercio con la Nueva España por temor a nuevos ataques ingleses ${ }^{45}$. Esta falta de remisiones regulares había sumido a las Filipinas y a las Marianas en una grave crisis económica que el gobernador y capitán general, don Gaspar de la Torre, había referido en diversas cartas al zaragozano Pedro Cebrián y Agustín (1687-1752), conde de Fuenclara, Virrey de Nueva España (1742-46) ${ }^{46}$.

Ante esta situación, la Corona no podía optar por reducir sus efectivos en el presidio de las Marianas. Más bien al contrario. Así, el 5 de octubre de 1745, la secretaria de Estado dictaminó a favor de reforzar en lo posible su presencia en las islas, porque

(...) teniendo en Manila las razones de conveniencia y necesidad para la permanencia de dicho Presidio como escala que es para los galeones del comercio de Filipinas con Nueva España y adonde llegan a hacer aguarda y bastimentarse de lo que

44 Rodríguez García, 1976: 86-87.

45 El 20 de mayo de 1742 Ansón capturó el galeón «Nuestra Señora de Covadonga» a la entrada del estrecho de San Bernardino, a las puertas de Manila. Sobre sus actividades piráticas, véase su Viaje alrededor del mundo, hecho en los años desde 1740 al 1744 (1833). Véase también la carta que el gobernador y capitán general de las islas Filipinas, don Gaspar de la Torre, escribió al rey, con fecha en Manila, 26 de julio de 1745, en la que refiere la captura del patache "Covadonga» a manos del comandante Ansón (AHCJC. FILPAS-092, f. 74r). Sobre este comandante inglés y las consecuencias de dicha captura, véase Rodríguez García, 1976: 174-75; Cabrero, 2000: 266-67; 271; Carano \& Sánchez, 1965: 94-101.

46 El gobernador de las Filipinas, don Gaspar de la Torre, escribió una carta al Virrey de la Nueva España, con fecha en Manila, 22 de agosto de 1745, en la que le comunicaba la inminente llegada de una escuadra inglesa desde Batavia a las Filipinas. Las cajas reales se hallaban sin fondos suficientes, por lo que el gobernador solicitaba que enviase situado de los cuatro años anteriores así como soldados y armas ante la dificultad de mantener las tropas y defender debidamente las islas (AHCJC, FILPAS-092, f. 78v; 435r). A resultas de ello, el Virrey de la Nueva España escribió al rey, con fecha en Ciudad de México, 14 de marzo de 1746, en la que le comunicaba el miserable estado en el que se encontraban sus vasallos de las islas Filipinas después de la pérdida del patache «Nuestra Señora de Covadonga» (AHCJC. FILPAS-092, f. 71r). Tras la muerte del gobernador de la Torre (1745) el obispo electo de Nueva Segovia, fray Juan de Arrechedera, gobernó interinamente hasta que el cacereño don Francisco José de Ovando, marqués de Ovando, jefe de la escuadra del mar del Sur, ocupó el cargo como nuevo gobernador de las Filipinas (1750-54). Dicho nombramiento se expidió en una Real Cédula de fecha 18 de agosto de 1746 por la que además se encargaba al Virrey de Nueva España que se le concediera el valor de un situado para atender las necesidades que había padecido su antecesor en el gobierno (AHCJC. FILPAS-092, ff. 434-435). 
necesitan principalmente de carnes por la abundancia de ganados que producen estas islas nunca podían pensar ni proponer esta reforma, pues las mismas causas que da el padre Calvo de la disminución de sus naturales hacen más precisa la guarnición pues esta sirve para mantener el puesto y la situación de aquellas islas e impedir se establezcan en ella enemigos de nuestra Corona, lo que sería de gravísimo perjuicio a las islas Filipinas, y a su comercio ${ }^{47}$.

Pero no había recursos para ello y la situación, lejos de mejorar, parecía empeorar. En septiembre de 1747, el capitán don Jorge Eduardo del Castillo, secretario de la Gobernación y Guerra, lamentaba que el sargento mayor don Miguel Fernández de Cárdenas no hubiera dejado ni medio real en las cajas reales, lo que obligó al gobernador entrante a solicitar préstamos a los generales de los galeones para atender los gastos de mantenimiento a cuenta de los situados debidos ${ }^{48}$. La solución pareció llegar un 18 de julio de 1747 cuando las naves capitana «Nuestra Señora del Rosario» y almiranta «Nuestra Señora del Pilar» anclaron en el puerto de Umatac. El general y maestre de campo don Francisco González de Quijano tenía órdenes de entregar el situado que transportaba al sargento mayor don Miguel Fernández de Cárdenas o a su apoderado, pero al no encontrarse en las islas, decidió llevarlo directamente a Mani$1 \mathrm{a}^{49}$. En la nao capitana iba el arzobispo de Manila entrante, fray Pedro de la Santísima Trinidad ${ }^{50}$. El gobernador Gómez de la Sierra y los padres jesuitas trataron de convencerlo por todos los medios, pero «sin poder conseguirse el que se conferenciara otro negocio por no haber sido posible el que dentro de tan tiempo (...) se juntasen las personas que habían de concurrir a determinarlo» ${ }^{51}$.

47 AHCJC. FILPAS-092, f. 54v.

48 AHCJC. FILHIS-061. E-I-c5 [r] Cuadernillo «Muerte de Felipe V y Coronación de Fernando VI (1747) en Agaña Marianas», ff. 12r-14r; 18v. En octubre de 1747 el gobernador Gómez de la Sierra tenía dos sargentos mayores: el primero, don Miguel Hernández de Cárdenas, antiguo gobernador interino de las islas, y el segundo, don Diego de Aristizabal, que cobraban 5.000 pesos cada uno a modo de sueldo (AGN, «Copia auténtica del título de gobernador y capitán general de estas islas Marianas al padre don Henrique de Olavide y Michelena, instrucción y demás diligencias con el obedecimiento y posesión de este referido gobierno», Indiferente Virreinal, Caja 4318, Exp. 15, ff. 8v-10r).

49 Como bastimentos solamente se avino a dejar el paño, sombreros y jabón (AHCJC. «FILHIS-061. E-I-c5 [r] Cuadernillo «Muerte de Felipe V y Coronación de Fernando VI (1747) en Agaña Marianas», ff. 14r; 17r). Véase también AHCJC. FILPAS-093, ff. 14r-14v.

$50 \mathrm{Su}$ nombre de pila era Martínez de Arizala. Contaba por entonces 52 años y desde 1730 había servido como oidor en la Audiencia de Quito (Lévesque, History of the Micronesia, Vol. 14, 1999, p. 26).

51 AHCJC. FILHIS-061. E-I-c5 [r] Cuadernillo «Muerte de Felipe V y Coronación de Fernando VI (1747) en Agaña Marianas», f. 14r. 
Al día siguiente, el arzobispo saltó a tierra para anunciar las tristes y buenas nuevas de la muerte y coronación del nuevo rey así como para celebrar el sacramento de la confirmación. Para comenzar los preparativos de las ceremonias reales en Agaña era necesaria una Cédula Real autorizando formalmente la celebración de las exequias reales u honras fúnebres y coronación de los reyes difunto y reinante. El Virrey, o gobernador, la sostenía sobre su cabeza, y siguiendo el ritual, juraba obedecer lo mandado en ella. A pesar de no contar con ninguna autorización real, el gobernador Gómez de la Sierra se otorgó la autoridad necesaria para celebrar los festejos con las demostraciones de amor y lealtad correspondientes ${ }^{52}$. Hacía casi un año de la muerte de Felipe V y Gómez de la Sierra no quería dejar pasar la oportunidad por considerar que se trataba de una obligación de su cargo ${ }^{53}$. Para ello solicitó un préstamo a cuenta de los tres situados que se hallaban detenidos en Nueva España con el fin de aliviar las necesidades de la infantería y poder celebrar las festividades programadas.

\section{2. ¿EL REY EN LAS Marianas?}

A mediados del siglo XVIII San Ignacio de Agaña había adquirido el estatus de una ciudad colonial, con los edificios públicos — palacio, cabildo, iglesia, colegio, etc. - ocupando el centro de la plaza mayor. Fue allí donde las

$52 \mathrm{Al}$ respecto consideraba «ser este gobierno muy obligado a manifestar en este Real Presidio como tan favorecido de su Real Magnificencia el gran celo y amor que le tiene, publicando con actos correspondientes las predichas noticias, no obstante la falta de Superior Mandato, el que puede retardarse por las guerras impidiendo la navegación de los bajeles que pudieran conducirlo de las islas Filipinas a estas de Marianas» (AHCJC. FILPAS-093, Doc. 66, ff. $1 \mathrm{r}-1 \mathrm{v})$. En este sentido, contrasta con las celebraciones que en 1725 hizo su antecesor, don Manuel de Argüelles, quien sí que recibió una Real Cédula que fue leída el 20 de septiembre de 1725 por su secretario de la gobernación, el capitán don Nicolás Guerrero, ante los vecinos principales de Agaña (AHCJC. FILHIS-061. E-I-c5 [r] «Cuadernillo Muerte de Felipe V y Coronación de Fernando VI (1747) en Agaña Marianas», f. 2r. Véase también AHCJC. FILPAS-093, Doc. 66, f. 2r).

53 AHCJC. FILPAS-093, Doc. 66, ff. 1r-1v. Como apunta Osorio, las ceremonias reales se celebraban a partir de la llegada de una cédula real (2004: 454; 459; 2004b: 21). No fue este el caso, puesto que a su llegada a la ciudad de Manila, después de haber ejercido como gobernador por espacio de cuatro años (1746-50), el 25 de febrero de 1750 solicitó que se aprobaran los gastos que hizo - en concreto, 3.144 pesos - para las celebraciones de exequias y coronación de los reyes, «no obstante de no tener mandato para ella» (AHCJC. FILHIS-061. E-I-c5 [r] «Cuadernillo «Muerte de Felipe V y Coronación de Fernando VI (1747) en Agaña Marianas», f. 26v; AHCJC. FILPAS-093, Doc. 66, ff. 28r-29v. Véase también Driver, 1984: 33). 
autoridades civiles habían dispuesto la organización de las honras y sufragios en honor de sus reyes, promulgados por bando o pregón en toda la isla de Guam. Así, el 26 de julio, por la noche, empezaron las lúgubres demostraciones de luto y oraciones en la engalanada iglesia del Dulce Nombre de María hasta el alba, disparándose tres salvas de cañón a cada repicar de las campanas. Vestidos de negro, los vecinos y moradores de la ciudad acudieron al templo donde se encontraba el insigne túmulo de Felipe $\mathrm{V}$ para rezar por su alma, dando muestras públicas de su dolor ${ }^{54}$. Como apunta Alejandra Osorio, la tristeza del momento no se expresaba a través de una excesiva emoción, sino mediante unos ropajes «apropiados» que preservaban el «correcto» orden social $^{55}$. El objetivo no era otro que reafirmar públicamente las cualidades de las personas que los portaban, estableciendo diferencias sociales de acuerdo a su vistosidad y calidad ${ }^{56}$. Entraron en silencio, con las velas encendidas, mientras un escuadrón de soldados uniformados y enlutados, con sus banderas y tambores, marcaba el ritmo pausado de la comitiva que se dirigía a rendir el último homenaje al «monarca ausente». Cientos de luces parpadeantes chispeaban en la oscura nave de la iglesia simbolizando, como ha señalado Osorio, «el triunfo de la vida sobre la muerte ${ }^{57}$. Esta teatralización del sentimiento vivo de los fieles fue una extraordinaria función que establecía una conexión entre las dos naturalezas -o «cuerpos»- del Rey» ${ }^{58}$. Por un lado, el monarca poseía un

54 La muerte de los reyes y sus familiares había sido siempre motivo de duelo (Varela, 1990). En 1718, el arzobispo-gobernador de Manila escribió a Felipe V en la que expresaba sus condolencias por la pérdida de su abuelo, el rey francés Luis XIV, y le notificaba haber hecho «de mi parte alguna demostración, aunque corta, de mi grande obligación determiné oficiar de pontifical como lo hice en la función fúnebre de las honras y exequias que el día 11 de corriente («Carta del Arzobispo de Manila [fray Francisco] a SM da cuenta con testimonio de haber recibido la Real Cédula del 30 de marzo de1715 en que se le participa la muerte del rey de España y de haberse ejecutado las exequias y demás sufragios correspondientes así en su iglesia como en los demás obispados sufragáneos de aquellas islas», Manila, 18 de julio de 1718 (AHCJC, Documentos Manuscritos Historia de las Filipinas (FILPAS), n. ${ }^{\circ}$ 74, 1718 1719, ff. 52r-54r). No tenemos constancia de que se hubiera hecho un acto semejante en las Marianas.

55 Osorio, 2004b: 23-24.

56 Osorio, 2004: 462; Osorio, 2004b: 23-25.

57 Osorio, 2004: 464; 2004: 26.

58 Esta bipartición de la persona divina se basaba en la distinción medieval de los dos cuerpos o naturales de Cristo. Por un lado, una naturaleza individual, que aludía a la presencia «real» de Cristo en la Eucaristía (corpus verum, corpus naturale o Corpus Christi), y otra colectiva, que hacía referencia a la iglesia como cuerpo organizado de la comunidad cristiana (corpus mysticum). Al respecto, véase Kantorowicz 1957. Quiero agradecer a Isabel Valverde, a Juan Carlos Garavaglia (UPF) y a Alejandra Osorio (Wellesley College) el haber llamado mi atención sobre este magistral texto. 
cuerpo mortal que estaba sujeto a las eventualidades — enfermedades, accidentes - de la vida de cualquier ser humano, lo que lo situaba al mismo nivel que sus súbditos (Corpus Christi). Por el otro, su cuerpo «político» aspiraba a la inmortalidad del Fénix y revelaba las cualidades perpetuas del absolutismo monárquico (corpus mysticum). El funesto ritual revelaba esta doble función: la muerte física de Felipe $\mathrm{V}$ y la continuidad de la monarquía en la figura de su hijo y heredero, lo que solventaba, como diría Bouza, «el indeseable hiato de los períodos de interregno» ${ }^{59}$.

Fue una larga ceremonia que duró toda la noche y en la que los símbolos y las imágenes religiosas jugaron un papel fundamental. El funeral contó con la participación de los cinco jesuitas que habían sido convocados a tal efecto y se cerró con la lectura de una oración fúnebre a través de la cual rendía homenaje al monarca cuya vida, supuestamente virtuosa, había merecido una buena muerte y alcanzado la gloria eterna ${ }^{60}$. Finalizados los oficios divinos, el gobernador, como alter ego del monarca, se retiró al palacio en donde recibió el pésame de los vecinos, la mayoría de oficiales retirados y soldados que vivían en las islas, a los que exhortó a portarse con amor y fidelidad al servicio del nuevo rey. Acto seguido llamó al secretario don Jorge Eduardo del Castillo para que convocara por la tarde a los pobres, viudas y enfermos de Agaña para darles una limosna. Acudieron ocho leprosos y doce viudas, a quienes se repartieron cien piezas de plata, de todo lo cual fueron testigos los capitanes don Fernando Estanislao de Agüero, don Juan Antonio Rotea y el teniente de los Reales Almacenes, don Joseph Guerrero, quienes les encomendaron que en señal de agradecimiento rogasen a Dios por el rey difunto (Felipe V) y por la salud del nuevo soberano (Fernando VI) ${ }^{61}$.

Este sentimiento de lealtad y poder se basaba en una deuda de gratitud a la Corona que continuaba con la entronización del rey reinante. La tristeza por la muerte de Felipe V se mudó en regocijo y alegría por la llegada de un nuevo monarca a quien había que jurar públicamente obediencia y sumisión. El difunto fue expuesto en la iglesia durante tres días al público asistente, poco acostumbrado a las noticias y novedades, para ver algo que no veían con frecuencia: el féretro de un rey ausente ${ }^{62}$. El 28 de julio, por la mañana,

59 Bouza Álvarez, 1994: 40.

60 AHCJC. FILPAS-093, Doc. 66, ff. 7r-9r.

61 AHCJC. FILHIS-061. E-I-c5 [r] «Cuadernillo «Muerte de Felipe V y Coronación de Fernando VI (1747) en Agaña Marianas», ff. 6v-7r; AHCJC. FILPAS-093, Doc. 66, f. 8r. Véase también Driver, 1984: 27.

62 Dicho ritual funerario siguió el que se celebró en Madrid (14-16/07/1746) donde el cuerpo de Felipe $\mathrm{V}$ fue expuesto en el palacio durante tres días al público. 
el pregón anunció la feliz coronación de Fernando VI'63. Para celebrarlo, el capitán Jorge Eduardo del Castillo, secretario del gobernador, leyó un decreto por el que se ordenaba distribuir 16.040 pesos en metálico entre los aproximadamente 140 soldados que integraban las infanterías española y pampanga en concepto de catorce meses de paga a cuenta que la Corona les debía desde hacía más de cuatro años ${ }^{64}$. A dicho decreto siguió el del día 31 del mismo mes por el que se les notificaba el prorrateo en metálico y géneros que tocaba a cada uno de los soldados y oficiales de la infantería española (125 pesos) y pampanga (40 pesos) ${ }^{65}$. A la falta del salario se unía la corrupción de los gobernadores, quienes compensaban los diez mil pesos que pagaban de fianza en Manila con diversos negocios lucrativos ${ }^{66}$. En esencia, especulaban con el situado obligándoles a comprar a precios desorbitados, por lo cual los soldados casados vestían harapos y sus mujeres andaban casi desnudas sin avíos con los que asistir a misa. Esta era la opinión del procurador jesuita Joseph Calvo, quien recomendaba al rey que los misioneros se encargaran de la distribución del salario,

porque de esta suerte podrían cada mes los soldados llevarse a sus casas sus sueldos con que a mediana economía tendrían con que comprar a precio cómodo en el barco que cada dos años va de socorro, las cosas de que necesitasen y aún podrían prevenirse encomendándolas a Manila para que les fueran más baratas; y no les sucediera lo que ahora que con una mano se cuenta para la paga del soldado, y con la

63 Su coronación oficial tuvo lugar en Madrid, el día 10 de octubre de 1746.

64 Según informe con fecha en México, 15 de marzo de 1746, el situado anual de las Marianas ascendía unos 20.550 pesos, de los cuales 11.400 pesos correspondían al salario del gobernador, y 825 pesos al salario del sargento mayor (AGN, Instituciones coloniales, Indiferente Virreinal, Caja 4318, Expediente 28, f. 2v). En los casi cinco años que no había llegado el situado a las Marianas, la Corona debía más de 30.000 pesos. Los generales de los galeones de 1747 accedieron a pagar el situado siempre y cuando no sobrepasara los 10.000 pesos anuales (AHCJC. FILHIS-061. E-I-c5 [r] Cuadernillo «Muerte de Felipe V y Coronación de Fernando VI (1747) en Agaña Marianas», ff. 4-5v; 7v; 24v. Hay copia en el volumen «Islas Marianas y Bohol, 1725-1858», ff. 11-47). Para más información, véase también AHCJC. «FILCAR. E.I, a-18. Cartas de misioneros, 1677-1750», ff. 250-251 y AHCJC. FILPAS-093, ff. 5v; 8r-8v. Véase también Tueller 2001, 392.

65 AHCJC. «FILHIS-061. E-I-c5 [r] Cuadernillo «Muerte de Felipe V y Coronación de Fernando VI (1747) en Agaña Marianas», f. 18v; «Report on ceremonies held in Guam at the coronation of Fernando VI, etc.», en Lévesque, 14 (1999: 28). En 1711 el salario de un soldado de la infantería española era de unos 315 pesos anuales. El comandante del real presidio recibía la mitad del sueldo del gobernador, esto es, unos 1.600 pesos (Hezel, 1989: 35; Brunal-Perry, 2004: 554-555).

66 En tiempos del gobernador Gaspar de la Torre se consideró la posibilidad de disminuir dicha fianza «si la situación económica del gobernador así lo aconsejaba» (Rodríguez García, 1976: 86). 
otra para la paga del gobernador por las cosas que compraron, las que por lo excesivo del precio no alcanzaran a satisfacer su necesidad, y así andan pobres y endeudados ${ }^{67}$.

Por el contrario, el secretario Jorge Eduardo del Castillo lo atribuía al juego de sus maridos y a «otros vicios», como el tabaco, que se habían extendido entre la población. El 26 de mayo de 1720 el sargento mayor Joseph de Quiroga y Losada había escrito una carta a Felipe V en la que denunciaba este mal ejemplo que sumía a las familias en la pobreza. Los soldados se gastaban su plata y todo cuanto tenían de valor en apuestas, prostitutas y bebida que causaban muchas muertes y miseria generalizada ${ }^{68}$. Para remediar esta corrupción moral, el secretario distribuyó «generosamente» la ropa y bastimentos de los avíos que el gobernador había traído desde Manila en el patache de 1746. Asimismo, autorizó a los oficiales y mercaderes de dicho pasaje para que les fiaran lo que fuera necesario, contando siempre con el aval del gobernador. Finalmente, convocó a las mujeres a las puertas del palacio real y ordenó al capitán Tomás Verdugo que les proporcionara algunas provisiones, vestuarios y bastimentos de los reales almacenes, costeándolo todo a sus expensas, con las que pudieran aliviarse de sus miserias y garantizar así el éxito de los festejos ${ }^{69}$.

El bando señaló tres días festivos a partir del sábado 29 por la noche. Todas las calles de la ciudad sustituyeron las bayetas negras por guirnaldas y flores, iluminándose con luces y antorchas, en especial los balcones del palacio y casas principales, que lucían colgaduras y resplandecían refulgentes mientras sus habitantes se reunían en la plaza mayor aclamando vivas al rey y a la reina consorte doña María Bárbara de Braganza (1711-1758), esperando alcanzar algunas de las monedas que arrojaban. El domingo siguiente, de madrugada, las calles de Agaña se llenaron de gente que iba y venía a la iglesia o al palacio del gobernador, que apareció ricamente empavesado de ricas colgaduras, festones de flores y plumas de colores, mientras la artillería hacía las salvas de honor para la misa de gracias ${ }^{70}$. Un escuadrón permanecía con sus armas en el patio de la iglesia cuyo altar mayor estaba ricamente adornado con flores y

67 Memorial de José Calvo al Rey, con fecha en Manila, 20 de junio de 1737, en AHCJC. FILPAS-092, f. 51r.

68 Driver 1992, 104.

${ }^{69}$ Las fuentes señalan que los Almacenes Reales contaban con 500 botellas de vino de jerez, 40 tinajas de harina y 12 de trigo (AHCJC, «FILHIS-061. E-I-c5 [r] Cuadernillo «Muerte de Felipe V y Coronación de Fernando VI (1747) en Agaña Marianas», ff. 5r; 17v. Véase también AHCJC. FILPAS-093, Doc. 66, ff. 5v; 10v-11r).

70 AHCJC, «FILHIS-061. E-I-c5 [r] Cuadernillo «Muerte de Felipe V y Coronación de Fernando VI (1747) en Agaña Marianas», f. 8r. Véase también Driver, 1984: 28. 
guirnaldas. No fue hasta las tres de la tarde que apareció el gobernador, vestido de gala y secundado por un pequeño séquito integrado por los vecinos, capitanes y oficiales españoles, quienes ocuparon los primeros lugares. Tras ellos se agolpaba una multitud anónima que apenas tenía cabida en el recinto de la iglesia. La misa se acompañó de una música suave apenas interrumpida por las salvas de la fusilería. Acabada la ceremonia, con gran repique de campanas los asistentes cantaron solemnemente uno de los himnos litúrgicos más antiguos de la cristiandad: el Te Deum Laudamus, acompañados de música de clarines y chirimías, cerrándose el acto con una descarga general ${ }^{71}$.

A continuación, el gobernador se retiró al palacio, donde recibió las enhorabuenas y honores que le correspondían como responsable de la función. Para resaltar su magnanimidad y benevolencia liberó algunos reos presos que no tenían delitos graves, publicando un perdón general que decretó para todos los huidos y desertores, como era costumbre, cuando nacía o moría un rey ${ }^{72}$. Por la noche volvieron a verse los resplandores de las antorchas que iluminaban la plaza mayor, donde hubo un baile de mascaradas «que fue de mucho placer por la novedad» $\gg^{73}$. La aceptación pública de los símbolos de poder, así como las muestras de obediencia y lealtad de sus súbditos, legitimaban el poder que el rey había depositado en sus gobernadores y capitanes generales ${ }^{74}$.

Al alba del día siguiente, lunes 30, la artillería saludó con estruendo de fuego la fiesta de San Ignacio de Loyola, patrón de Agaña y de la iglesia del Dulce Nombre de María, lo que sacó a una multitud de ambos sexos a la ca1le. Permanecieron en la plaza, de pie, ovacionando al rey y al santo patrón delante de un lujoso catafalco que se había preparado en honor de Fernando VI. Estaba adornado de alfombras y ricas colgaduras en un elevado y suntuoso sitio, que lucía con esmero la realeza de su inquilino ${ }^{75}$. A las dos de la tarde, los instrumentos y los disparos de salva de los arcabuceros anunciaban la llegada del monarca. Poco a poco la plaza se iba llenando de gente que se

71 AHCJC. FILPAS-093, Doc. 66, f. 9r.

72 También era costumbre liberar presos durante la Cuaresma, como habían hecho los judíos con Barrabás.

73 AHCJC, FILHIS-061. E-I-c5 [r] Cuadernillo «Muerte de Felipe V y Coronación de Fernando VI (1747) en Agaña Marianas», ff. 8v. Véase también Driver 1984, 29.

74 Viqueira Albán, 1999, p. 83.

75 Como señala Osório, el catafalco que se construyó en Lima para las exequias de Felipe III tenía «espacio para más de tres mil velas cuya magnificencia, de acuerdo con Mugaburu, resaltaba aún más en la oscuridad producida por los cortinajes de damascos negros y monedas de oro sevillanas (que reflejaban la luz titilante de las velas) que cubrían la totalidad de las murallas interiores de la catedral, así como el techo y su cúpula» (Osório, 2004b: 27). 
agolpaba frente al estrado cuando a las cuatro o cinco horas salieron del real palacio el gobernador Gómez de la Sierra, acompañado del sargento mayor del presidio, don Francisco de Mier, quien portaba el real retrato con una escolta de diecisiete capitanes y demás oficiales armados con fusiles y bayonetas caladas. Ataviado con sus mejores galas, su hijo primogénito, don Juan Joseph Garcés de la Sierra, actuaba como alférez mayor en la ceremonia de coronación, haciendo las debidas demostraciones de obediencia y lealtad al monarca a las que siguió las salvas de la artillería ${ }^{76}$. Al entrar en la plaza el público se descubrió, permaneciendo en silencio mientras el alférez mayor colocaba al rey en el sitial prevenido a tal efecto y la escolta, a sus pies, mostraba así el mayor respeto y lucimiento de la monarquía. El rey, ciertamente, no estuvo nunca en las Marianas, pero aquella coronación tuvo un efecto «real» (en el doble sentido de regio y veraz) porque fue capaz de representar al rey ausente como si efectivamente estuviera allí a través de la relación simbólica que establecía con los objetos ${ }^{77}$. Luego el gobernador se dirigió a la plebe con estas palabras,

Caballeros, aunque a los menos entendidos les puede servir de nota el yo asista a este acto, deben tener presente que donde está el retrato del rey, mi Señor, no puedo yo estar de más! ${ }^{78}$.

Muchos retratos, estampas o pequeñas imágenes del rey ausente habían sido distribuidos a lo largo y ancho del imperio para celebrar la misma liturgia del poder real. Réplicas que aseguraban la presencia del gobernante en lugares remotos y que constituían, como ha señalado Osorio, elementos fundamentales de su soberanía ${ }^{79}$. Acto seguido, llamó a dos de sus ayudantes que portaban unos quinientos pesos en dos fuentes de plata, y tomándolos en un puño los fue distribuyendo entre los ávidos asistentes hasta que quedaron vacías, exclamando,

76 Durante la ceremonia de coronación del efímero reinado de Luís I, el gobernador Argüelles había hecho lo propio con su hijo (AHCJC, FILHIS-061. E-I-c5 [r] Cuadernillo «Muerte de Felipe V y Coronación de Fernando VI (1747) en Agaña Marianas», f. 2). Véase también Driver 1984, 30-31.

77 Sobre la «presencia real» del rey en las posesiones de ultramar, véase Osório, 2004: 447-474.

78 AHCJC. FILHIS-061. E-I-c5 [r] Cuadernillo «Muerte de Felipe V y Coronación de Fernando VI (1747) en Agaña Marianas», ff. 9v. Véase también AHCJC. FILPAS-093, Doc. 66, f. 10 r.

79 A mediados del siglo XVIII, los retratos fueron progresivamente sustituidos por estampas impresas distribuidas entre los asistentes (Osorio 2004, 450; 471; 2004b, 34). En las Marianas, las imágenes gráficas de los monarcas parecían no haber sustituido todavía la gramática visual de los retratos. 
Caballeros, yo quisiera haber tenido posibilidad para que estas monedas fueran de oro $^{80}$ y en ellas [estuviera] estampada la imagen de nuestro soberano monarca para que sirviesen de llaves a los corazones para introducir en ellos el más fino amor a nuestro Rey y Señor ${ }^{81}$.

En efecto, los retratos, emblemas y epigramas, las medallas conmemorativas o efigies reales grabadas en monedas constituían formas simbólicas que sustituían a los monarcas, transmitiendo una sustancia «real» a las cosas que los representaban ${ }^{82}$. Al carecer de su imagen regia, esa ausencia podía interpretarse como un amor disminuido hacia sus súbditos ${ }^{83}$. Sus intereses $-\mathrm{y}$ los de sus administradores y representantes en Indias - no podían estar sobre los de la comunidad. Su deber fundamental consistía en la administración de justicia, procurando la seguridad y bienestar de su pueblo ${ }^{84}$. Actuando en representación del bien público, el gobernador Gómez les recordó en su discurso que a pesar de las distancias y las guerras no los había olvidado. Como prueba de su amor, la redistribución generalizada en forma de monedas - la «parte maldita» de George Bataille ${ }^{85}$ - constituyó un elemento de cohesión social y participación colectiva, pero también de prestigio y reconocimiento social. De lo que se trataba era de evitar el menoscabo de la autoridad real, que podía resultar la suya propia.

Cuando acabó de pronunciar estas palabras, su hijo, el joven Alférez, alzó el pendón real por tres veces mientras profirió con voz fuerte vivas al rey y a la monarquía. A la tercera descarga repicaron las campanas y la multitud profirió diversas aclamaciones mientras se dio orden al escuadrón de arrojar las armas a tierra para que pudieran recoger algún grano de plata «de tan buena cosecha» y beneficiarse así de la largueza del gobernador, que con aquel gesto pretendía demostrar su desinterés y celo en el servicio del monarca. Su esposa, acompañada de unos padres jesuitas satisfechos, contemplaba la función desde el balcón del palacio ${ }^{86}$. Allí pudo ver como su hijo, recién nombrado capitán de una

80 Se refería a los escudos de oro, que desde 1750 equivalían a dos piezas de ocho reales.

81 AHCJC. «FILHIS-061. E-I-c5 [r] Cuadernillo «Muerte de Felipe V y Coronación de Fernando VI (1747) en Agaña Marianas», f. 9v. Véase también AHCJC. FILPAS-093, Doc. 66, f. 10 r.

82 Louis Marin, citado en Bouza 1998, 64-65; Osorio 2004, 472; Garavaglia 2007, 42.

83 Erróneamente, James B. Tueller señala que las monedas ya llevaban el perfil del soberano, Fernando VI (Tueller, 2001, 392).

84 De la Puente Brunke, 2006: 133-148.

85 En particular, véase la adquisición el rango en la teoría del «potlatch» (Bataille, 1987: 107-108).

86 El 5 de mayo de 1748, los cinco padres jesuitas de las Marianas certificaron la generosidad del gobernador Gómez de la Sierra en la celebración de los festejos, confirmado que cuan- 
de las compañías españolas ${ }^{87}$, arrojaba algunos puños (o pesos) de plata a los cuatro lados de la plaza que causaron en la muchedumbre nuevas satisfacciones. A continuación el secretario Jorge Eduardo del Castillo se dirigió a los oficiales y naturales de los pueblos y les leyó una carta, en lengua chamorra, que decía lo siguiente,

Hijos, Maestros de Campo y Oficiales de los pueblos y vosotros todos los naturales de estas islas, que os halláis presentes y convocados en esta plaza, sabed como este festivo aparato, esta plausible demostración, y este conjunto de alegrías y júbilos que veis es en celebridad, y aclamación de haberse coronado por rey de las Españas a nuestro señor don Fernando el Sexto (que Dios guarde) cuyo soberano retrato es el que se franquea a nuestro respecto y veneración en este sitial que miráis por muerte del señor don Felipe $\mathrm{V}$ (que en santa paz descanse) de cuyo católico real celo y benignidad habéis recibido incesantemente honras y beneficios así en vuestras almas con la manutención de tantos misioneros apostólicos y en vuestras vidas hijos y haciendas con la conservación de esta real presidio para vuestro seguro y defensa a costa de muchos millares de pesos de su Real Erario, habiendo su real propensión siempre atenta a vuestro alivio y aumento solicitado varias veces informes de vuestro estado para concederos los que habéis ya gozado y mucho mayores empezáis a experimentar de poco tiempo a esta parte y no dudéis (f. $10 \mathrm{v})$ se os continúe lo mismo por vuestro actual monarca y señor su dignísimo hijo, y como tal debemos con toda fidelidad, humildad y amor venerar y respetar obedeciendo sus reales preceptos que en su real nombre a vosotros se os dieren por sus ministros en estas islas, y para que participéis no solamente de esta alegría, júbilo y regocijo de la celebración de su real coronación, sino también de alguna merced o mercedes como no sea en detrimento de su real servicio y de nuestra sagrada religión podéis pedirla verbalmente o por escrito derechamente a mí que por el empleo de su gobernador represento - aunque indigno- su real persona, les prometo en su real nombre oírles y concederles como fuere arreglada a razón y justicia ${ }^{88}$.

do llegó a la tierra e hizo posesión de su gobierno la halló con la penosa carestía de bastimentos mayormente con la falta de situado que por cuatro años no había venido ni hasta el presente ha recibido alguno y por esta causa todos en general españoles y naturales estaban padeciendo grandes miserias y necesidades que llegaron a tanto que muchos no tenían ni sus familias con que salir a misa (...), y solo por las medidas y activas providencias que dio les sacó de tan lastimoso estado y desconsuelo procurándoles como les continua su total alivio y aumento en cuya verdad no es presumible duda alguna» (AHCJC. FILPAS-093, Doc. 66, ff. 26r-26v).

87 Según las fuentes existentes, en 1747 el presidio contaba con 156 soldados, distribuidos en dos compañías: una, española, con 89 soldados, y otra, pampanga, con 67 soldados (AHCJC. «FILHIS-061. E-I-c5 [r] Cuadernillo «Muerte de Felipe V y Coronación de Fernando VI (1747) en Agaña Marianas», ff. 15v-16v). Véase también AHCJC. FILPAS-093, ff. $10 \mathrm{r}-10 \mathrm{v} ; 16 \mathrm{v}$.

88 AHCJC. «FILHIS-061. E-I-c5 [r] Cuadernillo «Muerte de Felipe V y Coronación de Fernando VI (1747) en Agaña Marianas», ff. 10r-10v. Véase también AHCJC. FILPAS-093, Doc. 66 , ff. $10 \mathrm{v}-11 \mathrm{r}$. 
Tras la lectura de la declaración, el sargento mayor don Pedro Fernández Verdugo se dirigió a la multitud y después de lanzar vivas al rey arrojó más de doscientos pesos de plata menuda que todavía guardaban sus sirvientes en grandes bandejas. A una señal del sargento los soldados se apartaron, dejando paso a la muchedumbre que se amontonaba alrededor para que recogiera las monedas. Hecho esto, el gobernador y su hijo, acompañados de una comitiva, se retiraron al palacio, no sin antes colocar el pendón y el real retrato de Fernando VI en el balcón, justo encima del sitial que le habían preparado, donde estuvo nueve días para que el pueblo pudiera rendirle homenaje durante la celebración de los festejos. Las festividades se desdoblan, y si antes las ceremonias tenían un carácter «oficial», ahora adquieren un carácter mucho más profano y lúdico que favorece la participación popular. El gobernador costeó una plaza de toros provisional para la beneficencia pública donde hubo diversas corridas y espectáculos con animales adiestrados y lanzas que causaron un gran divertimento entre la población ${ }^{89}$. Lo barroco se mostraba, sobre todo, en estos espacios y de manera liminar, como unos códigos culturales a través de los cuales se reproducía lo que Baktín denominó el «espíritu de la plaza pública»»"

El 1 de agosto, por la noche, Agaña se hallaba iluminada con carros de música y luces que favorecía, en palabras de Juan Carlos Garavaglia, la «dinámica de los cuerpos» (en este caso, cuerpos físicos), y que ayudaron a animar la velada $^{91}$. Además de los espectáculos taurinos se escenificaron bailes en el palacio y dos comedias panegíricas que dieron rienda suelta a lo profano y lo carnavalesco. La primera, Del Cielo viene el buen Rey ${ }^{92}$, que tuvo lugar el dos de agosto, y la segunda, Amor hace hablar a mudos (también conocida como el Amante Mudo o La fuerza de la sangre $)^{93}$ celebrada el día 6 del mismo mes,

89 Para una relación de dichos y otros gastos que hizo el gobernador Gómez de la Sierra, véase Jorge Eduardo del Castillo, «Razón de dichas partidas de pesos», AHCJC. «FILHIS-061. E-I-c5 [r] Cuadernillo «Muerte de Felipe V y Coronación de Fernando VI (1747) en Agaña Marianas», ff. 22r-22v.

90 Baktín, 1988. A partir del siglo ilustrado, el significado de las corridas de toros como una forma de representar el orden social se transformó en un espectáculo popular (Viqueira Albán, 1999: 15-22). En la Ciudad de México las corridas se improvisaban en distintos lugares, principalmente en la Plaza del Volador, a un lado del Real Palacio, Al respecto, véase AGN, Ramo Bandos, Vol. 7, Exp. 88, ff. 372-373, citado en Marley, 1983.

91 Garavaglia, 2007: 43. Sobre el carácter sacrificial del mundo taurino y su carácter religioso, véase Garavaglia, 2007: 47-53.

92 Esta comedia fue escrita por Rodrigo de Herrera y Ribera (1592-1657), dramaturgo contemporáneo de Lope de Vega (De la Barrera y Leirado, 1968: 183-184).

93 Esta famosa comedia fue escrita por los dramaturgos Sebastián Rodríguez de Villaviciosa (1618-63), Juan de Matos Fragoso (1608-1689) y Juan de Zabaleta (1610-1670) (De la Barrera y Leirado, 1968). 
en la que participó el capitán don Fernando Estanislao de Agüero, que hizo una alabanza pública al monarca y a continuación fue «secuestrado» por la plebe, que acto seguido lo trasladó al cementerio con la intención de enterrarlo. Allí lo esperaban los sacristanes y monaguillos, los cuales, prevenidos, escenificaron un entierro formal «aunque por ver si resucitaba no le dieron sepultura». A continuación lo trajeron de vuelta al palacio, donde el gobernador volvió a lanzar puños de plata menuda a la plebe que lo acompañaba, «sin que al muerto le pudiesen valer sus pies, y resurrección, pues a todo atendían para subirlo a palacio donde fue rescatado sin ser cautivo, con cuya burlesca fue singular el regocijo a que siguió la comedia que cerró y dio fin a todo» ${ }^{94}$.

Se trataba de unas celebraciones en las que abundaban en la risa, la fiesta y la confusión y en las que los espectadores se convertían en actores de la misma representación, si bien cada uno tenía un papel diferente de acuerdo a su posición social. Al potenciar lo cómico, lo burlesco y lo lúdico, estas piezas teatrales se alejaban de lo trágico de la Contrarreforma y promovían abiertamente la participación popular. Una dramaturgia participativa - cuyos excesos, dicho sea de paso, tenían mucho de dionisíaco - en la que era necesario regular la libertad de los participantes -y la de sus cuerpos ${ }^{95}$. Las autoridades civiles y religiosas trataron siempre de regular su carácter potencialmente «sedicioso», buscando cohesionar a los marianos alrededor de lo que Ruth A. Hill ha designado como el proyectismo de identidad de la dinastía borbónica. Un dirigismo cultural que durante el reinado de Fernando VI trató de edificar la nación española sobre la paz y el amor ${ }^{96}$.

Desde una perspectiva antropológica, la diversión nocturna, la escenificación del desorden y la satirización de los poderes locales promovía el «descontrol festivo» de los grupos plebeyos como resultado de la liberación de las tensiones sociales generadas por la corrupción de los gobernadores y alcaldes. Si las exequias y posterior coronación de Fernando VI fueron realmente «imaginadas» como la exaltación del orden político de los Borbones, estas prácticas festivas constituyeron la otra cara de Jano: una dislocación de la realidad cuya función lúdica posibilitaba al mismo tiempo la reproducción del totum social ${ }^{97}$.

94 AHCJC. FILHIS-061. E-I-c5 [r] Cuadernillo «Muerte de Felipe V y Coronación de Fernando VI (1747) en Agaña Marianas», ff. 11r-12r; AHCJC. FILPAS-093, Doc. 66, ff. 11v-12r. Véase también Driver, 1984: 33.

95 Viqueira Albán, 1999: 30.

96 Un ejemplo es El juicio de Paris renovado entre el Poder, el Ingenio y el Amor: Fábula épica para festejar la coronación del rey Fernando VI, escrita por Ignacio de Luzán para festejar la coronación de Fernando VI (citado en Hill, 2006: 63).

97 Viqueira Albán, 1999: 104-105. Como señala Garavaglia, no tiene ningún sentido analizar estas festividades de manera aislada, lo que nos obliga, como ya apuntara Marcel Mauss, a 


\section{CONCLUSIONES}

Hace algunos años José Antonio Maravall escribía que en la ciudad barroca del siglo XVII se organizaban fiestas y se montaban deslumbrantes fuegos de artificio, se exhibían ricos tapices o colgaduras de algodón, se construían arcos triunfales compuestos de ramas de árbol artísticamente entrelazadas, catafalcos para honras fúnebres y ceremonias de coronación, para preguntarse acto seguido dónde podían contemplarse semejantes conmemoraciones, sino era en una gran ciudad ${ }^{98}$. Las Marianas, situadas en la periferia de ultramar, suponen un interesante contrapunto al no cumplir con los estándares establecidos por el ámbito cultural del Barroco hispánico ni con la sensibilidad estética del Rococó $^{99}$. La austeridad y pobreza de las islas no impidió, sin embargo, que tuvieran lugar las celebraciones lúdicas y festivas de su comunidad. En ambos casos, el ceremonial constituía un medio para mantener el orden establecido a través de un comportamiento altamente ritualizado que algunos historiadores han definido como el «teatro del poder» ${ }^{100}$. Una forma de representar alegóricamente la unidad indisoluble entre la Corona y sus súbditos; o como recientemente ha señalado Ruth A. Hill, un nuevo concepto de comunidad o nación hispana basada en la idea «de hacer que los españoles abrazaran a sus reyes y se amasen entre sí» ${ }^{101}$.

Como hemos visto, la disminución demográfica de las Marianas llevó al procurador de los jesuitas, Joseph Calvo, a solicitar la reducción de los soldados del presidio. El objetivo era reforzar el presidio de Zamboanga y favorecer la conquista espiritual de los sultanatos de Joló y Tamontaca. En julio de 1747, poco antes de la celebraciones que tuvieron lugar en San Ignacio de Agaña, el padre Pedro de San Cristóbal informaba al monarca de su nombramiento como nuevo procurador de la Compañía en la provincia de Filipinas, y solicitaba permiso para viajar a Roma ${ }^{102}$. Allí escribió diversos memoriales $(14 / 08 / 1747$; 12/01/1748) al Consejo de Indias suplicando que se le concediera licencia para embarcar cuarenta sacerdotes y cuatro hermanos coadjutores — había solicita-

situarlas dentro de los universos simbólicos en las que se inscriben de manera lógica (2007: 54-55).

98 Maravall, 1975: 265. Aunque Maravall se refería al Barroco como un concepto histórico (siglo XVII) que «pertenece al ámbito total de la historia social» (1975: 48), utilizamos aquí el término «barroco» en relación a elementos estilísticos, puramente formales, que permanecían todavía vigentes en las exequias y ceremonias de coronación de las Marianas.

99 Seoane, 2000.

100 Viqueira Albá, 1999: 81-86. Garavaglia, 1999: 126.

101 Hill, 2006: 63.

102 AHCJC. FILPAS-093, Doc. 90, f. 63r. 
do más de sesenta sujetos - con destino a las Filipinas «por la falta que de ellos se experimenta en las misiones de las islas Marianas, Zamboanga, Joló y Tamontaca» ${ }^{103}$.

En sus Memoriales el procurador San Cristóbal no hizo ninguna mención de reducir las defensas de las Marianas. La Corona española no sólo mantuvo las plazas de dotación sino que las aumentó a $156^{104}$. Ante la firmeza de la Corona española en mantener las islas que fueron de los «Ladrones», la Compañía las incluyó en su demanda de misioneros ${ }^{105}$. En este contexto de crisis, el gobernador Gómez de la Sierra quiso representar el poder absoluto del monarca mediante unos protocolos palaciegos que le proporcionaron coherencia y autoridad. Los súbditos marianos jamás contemplaron al monarca «original», sino a un simulacro creado a través de representaciones iconográficas - retratos, emblemas, grabados, etc. - que les servía de recordatorio. No obstante, su presencia se percibió como algo sumamente real.

La lógica de estas prácticas ceremoniales - la exhibición pública de su retrato, el lanzamiento de monedas al aire y la fiesta posterior- no era un simple capricho de su símbolo viviente, el gobernador. Tenía que ver con unas formas ritualizadas de «fabricar» la monarquía, como diría Peter Burke (1992), en las Marianas. Un eficaz instrumento utilizado por las autoridades para promover la lealtad de sus súbditos. En este sentido, sorprende que James B. Tueller (2001) se pregunte «si el Rey Fernando VI sabía dónde estaba el pueblo de Agaña y si le importaba que los españoles, filipinos y nativos festejaran su reinado» ${ }^{106}$. La solemnidad del protocolo político ceremonial y su carácter público no se constituían de manera «irracional», sino que conllevaban un hondo simbolismo ${ }^{107}$. El contexto, sin embargo, era muy distinto al de las ricas cortes virreinales de Nueva España o del Perú descritas respectivamente por Cañeque (1996; 2004; 2004b) y Osorio (2004; 2004b). Nada más alejado del mundo áulico que las islas del Pacífico. Allí no había oro, ni esmeraldas, ni sedas con las

103 AHCJC. FILPAS-093, Doc. 107, f. 162r.

104 AHCJC. FILPAS-093, Doc. 66, f. 16v.

105 AHCJC. FILPAS-093, Doc. 92, ff. 121r-123v.

106 Tueller, 2001: 393.

107 En su estudio sobre la coronación de Felipe IV en lima (1622), Osorio señala que «las ceremonias reales sirvieron para hacer presente al Rey ausente y unirlo a sus vasallos en un «pacto» recíproco que necesitaba del ritual para hacerlo «verdadero» (2004b: 8). Más recientemente, Garavaglia ha estudiado las modalidades de difusión y publicidad del regalismo borbónico a través de las exequias de Carlos III y la proclamación de su sucesor en la ciudad de Buenos Aires (1789). Lejos de constituir un azar, este orden de los cuerpos — que no de los individuos- constituía «una proyección simbólica del orden social» (2007: 36-43). Sobre la imagen del rey en la Casa de Austria, véase Lisón Tolosana, 1991. 
que decorar el catafalco del rey. Lo realmente significativo no fue la largueza y generosidad del gobernador, sino las demostraciones de fidelidad que siguieron a las ceremonias. Si Dios establecía a los reyes como sus ministros terrenales y a través de ellos reinaban sobre los pueblos, las exequias, rogativas y consagraciones fortalecían su autoridad soberana y la de sus representantes, los gobernadores, quienes actuaban no sólo como autoridades políticas, sino como los defensores de sus intereses. Queda claro, pues, que el poder colonial en las Marianas quedó fijado a partir de unos simulacros políticos que garantizaron la continuidad del corpus mysticum de los Borbones — es decir, de Castilla y de las Indias - en los confines del imperio ${ }^{108}$.

\section{REFERENCIAS BIBLIOGRÁFICAS}

\section{a) Manuscritos}

Arxiu Històric de la Companyia de Jesús a Catalunya (AHCJC, Barcelona). «FILCAR. E.I, a-18. Cartas de misioneros, 1677-1750».

Arxiu Històric de la Companyia de Jesús a Catalunya (AHCJC, Barcelona). FILHIS-060 - E.I, c-06. Tomo «Islas Marianas y Bohol, 1725-1858».

Arxiu Històric de la Companyia de Jesús a Catalunya (AHCJC, Barcelona). FILHIS-061. E-I-c5 [r] Diversa sobre islas Marianas y Carolinas/ P. Sanvítores (1768). Cuadernillo «Muerte de Felipe V y Coronación de Fernando VI (1747) en Agaña Marianas».

Arxiu Històric de la Companyia de Jesús a Catalunya (AHCJC, Barcelona). FILPAS-092.

Arxiu Històric de la Companyia de Jesús a Catalunya (AHCJC, Barcelona). FILPAS-093.

Archivo Histórico de la Compañía de Jesús de la Provincia de Toledo (Alcalá de Henares), Sección Filipinas, C-285.

Archivum Historicum Societatis Iesu (ARSI), «Primus Catalogus Anni Personarum Anni 1746». Philippinae Cat. Trien. 1701-1755 1768, Tomo 3.

Archivum Historicum Societatis Iesu (ARSI), Litterae Annuae Philipp. 1663-1734 (etiam de Insuli Marianis), Tomo 13.

\section{b) Fuentes primarias}

Ansón, Jorge, Viaje alrededor del mundo, hecho en los años desde 1740 al 1744. Tomo II, Madrid, Imprenta de don Tomás Jordán, 1833. 
Marley, David (ed.), Documentos varios para la historia de la Ciudad de México a fines de la época colonial (1769-1815), México, Rolston — Bain, Vol. B-5, 1983.

\section{c) Fuentes secundarias}

Álvarez, Luís Alonso, «Repartimientos y economía en las islas Filipinas bajo dominio español, 1565-1815», Margarita Menegus (comp.), El repartimiento forzoso de mercancías en México, Perú y Filipinas, México: Instituto de Investigaciones Dr. José María Luis Mora \& Centro de Estudios sobre la Universidad - UNAM, 2000.

Baktín, Mijael, La cultura popular en la Edad Media y el Renacimiento, Madrid, Alianza Editorial, 1988.

Bataille, George, La parte maldita, precedida de la noción del gasto, Barcelona, Icaria - Antrazyt, [1967] 1987.

Fernando Bouza Álvarez, «La majestad de Felipe II. Construcción del mito real», José Martínez Millán (dir.), La corte de Felipe II, Madrid, Alianza Editorial, 1994.

Bouza Álvarez, Fernando, Imagen y propaganda. Capítulos de historia cultural del reinado de Felipe II, Madrid, Akal, 1998.

Brunal-Perry, Omaira, «La legislación de Ultramar y la administración de las Marianas: transiciones y legados», M. ${ }^{a}$ Dolores Elizalde Pérez-Grueso, Josep M. ${ }^{a}$ Pradera \& Luis Alonso (eds.), Imperios y naciones en el Pacífico. Volumen II. Colonialismo e identidad nacional en Filipinas y Micronesia, Madrid, CSIC, 2001: 395-406.

Burke, Peter, The Fabrication of Louis XIV, New Haven, Yale University Press, 1992.

Cañeque, Alejandro, «Theatre of Power: Writing and Representation the Auto de $\mathrm{Fe}$ in Colonial Mexico», The Americas, 52:3 (Saint Louis, 1996): 321-343.

Cañeque, Alejandro, «De sillas y almohadones o de la naturaleza ritual del poder en la Nueva España de los siglos XVI y XVII», Revista de Indias, vol. LXIV, 232 (Madrid, 2004): 609-634.

Cañeque, Alejandro, The King's Living Image: The Culture and Politics of Viceregal Power in Colonial Mexico (New World in the Atlantic World), New York, Routledge, 2004b.

Cabrero, Leoncio, Historia General de Filipinas, Madrid, Asociación Española de Cooperación Iberoamericana (AECI), 2000.

Carano, Paul \& Pedro C. Sánchez, A Complete History of Guam, Rutland, Vermont \& Tokio, Japón, Charles E. Tuttle Company [1964] 1965.

De la Barrera y Leirado, Cayetano Alberto, Catálogo bibliográfico y biográfico del teatro antiguo español: desde sus orígenes hasta mediados del siglo XVIII, Madrid, Imprenta de M. Ribadeneyra (reimpreso por Boydell \& Brewer) [1860] 1968. 
De la Costa, Horacio, The Jesuits in the Philippines, 1581-1768, Cambridge-Massachusetts, Cambridge University Press, [1961] 1989.

De la Puente Brunke, José, «Codicia y bien público: los ministros de la Audiencia de Lima seiscentista», Revista de Indias, 236, vol. LXVI (Madrid, 2006): 133-148.

Delgadillo, Yolanda Thomas B. McGrath \& Felicia Plaza, Spanish Forts of Guam, Guam, MARC-University of Guam, 1979.

Delgado, Juan José, SJ, Historia General Sacroprofana, politica y religiosa de las islas del Poniente llamadas, Filipinas, Manila, Imprenta de El Eco de Filipinas, 1892 [1751].

Díaz-Trechuelo López Spínola, María Lourdes, «The Economic Development of the Philippines in the Eighteenth Century», Philippine Studies, 11 (Manila, 1963): 195-231.

Díaz-Trechuelo López Spínola, María Lourdes, «Las Filipinas, en su aislamiento, bajo el continuo acoso», VV.AA, Historia General de España y América. América en el siglo XVIII. Evolución de los reinos indianos, Madrid, Rialp, 1984.

Díaz-Trechuelo López Spínola, María Lourdes, «Filipinas en el siglo XVIII: la Real

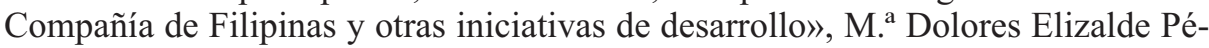
rez-Grueso (eds.), Las relaciones entre España y Filipinas. Siglos XVI-XX, Madrid, CSIC \& Casa Asia, 2002: 87-106.

Driver, Marjorie G., El Palacio. The Spanish Palace in Agaña. A Chronology of Men and Events, 1668-1899, Guam, MARC-University of Guam, 1984.

Driver, Marjorie G., «Notes and Documents. Quiroga’s letter to King Phillip V, 26 May 1720», Journal of Pacific History, 27 (Canberra, 1992): 98-106.

Driver, Marjorie G., The Spanish Governors of the Mariana Islands, Notes on their activities and the Saga of the Palacio. Their Residence and the Seat of Colonial Government in Agaña, Guam, Guam, Richard F. Taitano \& MARC \& University of Guam, 2005.

Farrell, Don A., History of the Northern Mariana Islands, Guam, Public School System of the Northern Mariana Islands, 1991.

Fradera, Josep Maria, «Filipinas en el siglo XIX: crecimiento económico y marco colonial», M. ${ }^{a}$ Dolores Elizalde Pérez-Grueso (eds.), Las relaciones entre España y Filipinas, Siglos XVI-XX, Madrid, CSIC \& Casa Asia, 2002: 107-122.

Galván Guijo, Javier (comisario). Islas del Pacífico: el legado español, Madrid, Ministerio de Educación y Cultura, 1998.

Garavaglia, Juan Carlos, «El teatro del poder: ceremonias, tensiones y conflictos en el estado colonial», J. C. Garavaglia, Poder, conflicto y relaciones sociales. El Río de la Plata, XVIII-XIX, Rosario, Homo Sapiens ediciones, 1999. 
Garavaglia, Juan Carlos, Construir el estado, inventar la nación. El Río de la Plata, siglos XVIII-XIX, Madrid, Prometeo Libros, 2007.

García-Abasolo, Antonio, «Ensayando una doble vía. La ruta Cádiz-Manila», VV.AA, El galeón de Manila, Madrid, Ministerio de Cultura \& Fundación Focus, 2000 .

Hezel, Francis X., SJ, From Conquest to Colonization: Spain in the Mariana Islands (1690 to 1740), Saipan, MP, Division of Historic Preservation, 1989.

Hezel, Francisc X. SJ, «Envoi: Spain and Mariana Islands in the Early Eighteenth Century», Glynn Barrat, The Chamorros of the Mariana Islands. Early European Records, 1521-1721, Guam, Occasional Historical Papers Series, n. ${ }^{\circ} 10$ Commonwealth of the Northern Mariana Islands, Division of Historic Preservation, 2003.

Hill, Ruth A., «Conquista y modernidad, 1700-1766. Un enfoque transatlántico», Pablo Fernández Albadalejo (eds.), Fénix de España. Modernidad y cultura propia en la España del siglo XVIII (1737-1766), Madrid, Marcial Pons Historia \& Universidad Autónoma de Madrid \& Universitat d'Alacant \& Casa Velázquez, 2006: $57-71$.

Kantorowicz, Ernst, The King's Two Bodies: A Study in Medieval Political Theology, Princeton, Princeton University Press, 1957.

Lévesque, Rodrigue, History of the Micronesia. A Collection of Source Documents. Volume 14 - Full Census of the Marianas, 1746-1773, Québec, Lévesque Publications, 1999.

Lisón Tolosana, Carmelo, La imagen del rey. Monarquía, realeza y poder ritual en la Casa de Austria, Madrid, Espasa Calpe, 1991.

Maravall, José Antonio, La cultura del Barroco, Madrid, Ariel, 1975.

Muñoz Barreda, Vicente, La Micronesia española o los archipiélagos de Marianas, Palaos y Carolinas, Manila, Tipografía «Amigos del País», 1894.

Osorio, Alejandra, «The King in Lima: Simulacra, Ritual, and Rule in Seventeenth-Century Peru», Hispanic American Historical Review, 84:3 (Durham, 2004): 447-474.

Osorio, Alejandra, El rey en Lima. El simulacro real y el ejercicio del poder en la Lima del diecisiete, Lima, Instituto de Estudios Peruanos-Documentos de Trabajo, 2004b.

Parry, John H., Trade and Dominion. The European Overseas Empires in the Eighteenth Century, New York, Praeser, 1971.

Rodríguez García, Vicente, El gobierno de don Gaspar Antonio de la Torre y Ayala en las islas Filipinas, Granada, Universidad de Granada, 1976. 
Stein, Stanley J. \& Barbara H. Stein, Plata, comercio y guerra. España y América en la formación de la Europa moderna, Madrid, Crítica [2000] 2002.

Seoane Pinilla, Julio, La politica moral del Rococó. Arte y cultura en los orígenes del mundo moderno, Madrid, Antonio Machado Libros-Colección la Balsa de la Medusa, 2000.

Sommervogel, Carlos, SJ. Bibliothèque de la Compagnie de Jesús...: bibliographie par les pères Augustin et Aloys De Backer...: histoire par le Père Auguste Carayon, 9 Tomos, Lovaina.

Stocklein, Joseph, Der Neue Welbott mit allerhand Nachrichten dern Missionariorum Societatis Iesu, Augusburg \& Viena, Philips, Martins \& Veith, 1960.

Varela, Juan, La muerte del rey. El ceremonial funerario de la monarquía española (1500-1885), Madrid, Turner, 1990.

Viqueira Albán, Juan Pedro, Propriety and Permissiveness in Bourbon Mexico, Wilminton, Delaware, SR Books, 1999 [1987].

Vitar, Beatriz, Guerra y misiones en la frontera chaqueña del Tucumán (1700-1767), Madrid, CSIC, 1997.

Fecha de recepción: 8-3-2010

Fecha de aceptación: 6-9-2010

\section{THE PHOENIX IN THE MARIANA ISLANDS (1747)}

This article analyzes the coronation ceremony of Ferdinand VI in the Mariana Islands and the funeral rites of his father, Philip $V$ that preceded it as a Baroque representation of power (1747). They were, in fact, two complementary functions that Alejandra Osorio has referred to as the "Two Faces of Janus", that were oriented to represent the figure of the Spanish monarch and to reinforce loyalty and fidelity among the subjects of the islands situated on the fringe of the empire.

Keywords: Jesuits, Mariana Islands, Ferdinand VI, Philippines, coronation. 